\title{
Vitamin E improves antioxidant status but not lipid metabolism in laying hens fed a aged corn-containing diet
}

\author{
X. M. Ding ${ }^{1}$, , Y. D. Mu ${ }^{1}$, K. Y. Zhang ${ }^{1}$, J. P. Wang ${ }^{1}$, S. P. Bai ${ }^{1}$, Q. F. Zeng ${ }^{1}$, and H. W. Peng ${ }^{1}$
}

\author{
* Corresponding Author: X. M. Ding \\ Tel: +86-13981603429, Fax: +86-28-86290922, \\ E-mail: dingxuemei0306@163.com \\ ${ }^{1}$ Institute of Animal Nutrition, Sichuan \\ Agricultural University, Key laboratory of \\ Animal Disease-resistant Nutrition, Ministry \\ of Education, Key laboratory of Animal \\ Disease-resistant Nutrition, Sichuan Province \\ Chengdu, 611130, China \\ ORCID \\ X. M. Ding \\ https://orcid.org/0000-0003-4298-4493 \\ Y. D. Mu \\ https://orcid.org/0000-0001-7304-3069 \\ K. Y. Zhang \\ https://orcid.org/0000-0002-2909-3357 \\ J. P. Wang \\ https://orcid.org/0000-0002-6596-8771 \\ S. P. Bai \\ https://orcid.org/0000-0002-5775-1900 \\ Q. F. Zeng \\ https://orcid.org/0000-0002-7184-0432 \\ H.W. Peng \\ https://orcid.org/0000-0002-5383-9075
}

Submitted Dec 7, 2019; Revised Jan 5, 2020; Accepted Mar 29, 2020
Objective: The objective of this study was to determine whether a dietary vitamin E (VE) supplement could alleviate any detrimental effects of aged corn on lipid metabolism and antioxidant status in laying hens.

Methods: The experiment consisted of a $2 \times 3$ factorial design with two corn types (normal corn and aged corn (stored for $4 \mathrm{yr}$ ) and three concentrations of $\mathrm{VE}(0,20$, and $100 \mathrm{IU} / \mathrm{kg}$ ). A total of 216 Lohmann laying hens (50 wk of age) were randomly allocated into six treatment diets for $12 \mathrm{wk}$. Each treatment had 6 replicates of 6 hens per replicate.

Results: The results show that aged corn significantly decreased the content of low-density lipoprotein cholesterol $(p<0.05)$, and reduced chemokine-like receptor $1(C M K L R 1) \mathrm{mRNA}$ expression $(\mathrm{p}<0.05)$ in the liver compared to controls. Diet with VE did not alter the content of crude fat and cholesterol ( $\mathrm{p}>0.05)$, or acetyl-CoA carboxylase, lipoprotein lipase, fatty acid synthase or CMKLR1 mRNA expression ( $p>0.05)$ in the liver among treatment groups. Aged corn significantly increased the content of malondialdehyde (MDA) $(p<0.05)$ and decreased superoxide dismutase (SOD) activity $(\mathrm{p}<0.05)$ in the liver. The VE increased the content of MDA $(\mathrm{p}<0.05)$ but decreased glutathione peroxidase (GSH-Px) activity in serum $(p<0.01)$ and in the ovaries $(p<0.05)$. Adding VE at 20 and $100 \mathrm{IU} / \mathrm{kg}$ significantly increased GSH-Px activity $(\mathrm{p}<0.05)$ in liver and in serum $(\mathrm{p}<0.01), 100 \mathrm{IU} / \mathrm{kg}$ VE significantly increased SOD activity $(\mathrm{p}<0.05)$ in serum. Aged corn had no significant effects on GSH-Px mRNA or SOD mRNA expression $(\mathrm{p}<0.01)$ in the liver and ovaries. Addition of $100 \mathrm{IU} / \mathrm{kg}$ VE could significantly increase $S O D$ mRNA expression $(\mathrm{p}<0.01)$ in the liver and ovary.

Conclusion: Aged corn affected lipid metabolism and decreased the antioxidant function of laying hens. Dietary VE supplementation was unable to counteract the negative effects of aged corn on lipid metabolism. However, addition of $100 \mathrm{IU} / \mathrm{kg}$ VE prevented aged corninduced lipid peroxidation in the organs of laying hens.

Keywords: Vitamin E; Aged Corn; Lipid Metabolism; Antioxidant; Laying Hens

\section{INTRODUCTION}

Research on the impacts of aged corn in the feed of production animals, such as laying hens, is increasing in importance due to long term storage in countries for the eventuality of a natural disaster. A considerable amount of these stored grains can be lost due to interactions among various physical, chemical, and biological factors associated with storage conditions [1]. Previous studies have shown that the quality and nutrient content of corn decreased with increased storage time [2]. A significant decrease in $\mathrm{pH}$, digestible lysine content, and thiamine content, as well as an increase in titratable acidity were observed when corn was stored for an extended period [3]. Further, corn lipids like fatty acids are susceptible to oxidation and rancidity [4]. Free fatty acid can be easily oxidized to produce $\mathrm{H}_{2} \mathrm{O}_{2}$, and thus affect catalase (CAT) and peroxidase (POD) activities in corn [5].

Feeding animals corn that has been stored long-term can cause adverse effects. Feeding 
aged corn resulted in reduced antioxidant function in broilers [6]. Ducks fed aged corn were more likely to have oxidative damage that reduced growth performance [7]. However, the effects of aged corn on lipid metabolism and antioxidant systems in laying hens remain largely unknown.

Vitamin E (VE) is a necessary fat-soluble vitamin for poultry. As a natural antioxidant, it plays an important role in scavenging free radicals, preventing lipids peroxidation, and protecting animals from the adverse effects caused by oxidative stress [8]. The VE improved antioxidant function of meat ducks fed aged corn diets [9]. Dietary supplementation with $200 \mathrm{mg} / \mathrm{kg}$ VE enhanced the antioxidant capacity of laying hens [10]. A previous study showed that VE could not prevent the visible yellow coloration of backfat and lipofuscin in pigs fed high oxidant diets, although it did decrease the extractable lipid content [11]. Our study aimed to determine if dietary supplementation with VE to hens fed aged corn could influence on lipid metabolism and antioxidant status.

\section{MATERIALS AND METHODS}

\section{Aged corn}

The aged corn used in this study was previously stored for 4 yr and was obtained from the national barns in Jilin, China. The control corn used in this study was stored for half a year and was obtained from Ningxia, China. All corn samples were stored in brick structures. Phytochemical properties of corn (Table 1) were the same as was previously published by Mu et al [12].

Table 1. Phytochemical properties of aged corn (stored for $4 \mathrm{yr}$ ) and normal corn (air-dried basis)

\begin{tabular}{lcc}
\hline \multirow{2}{*}{ Items } & \multicolumn{2}{c}{ Content } \\
\cline { 2 - 3 } & Aged corn & Normal corn \\
\hline Moisture $(\%)$ & 13.06 & 14.31 \\
Crude protein $(\%)$ & 7.73 & 7.56 \\
Gross energy (cal/g) & 3,846 & 3,799 \\
Crude fat $(\%)$ & 3.31 & 3.42 \\
Acidity of fatty acids $(\mathrm{KOH}$ mg/100 g) & 126 & 64 \\
MDA (nmol/mL) & 96.03 & 40.30 \\
CAT $(\mathrm{U} / \mathrm{mg})$ & 17.00 & 28.49 \\
POD $(\mathrm{U} / \mathrm{mg})$ & 34.26 & 64.93 \\
Aflatoxin $(\mu \mathrm{g} / \mathrm{kg})$ & - & 1.9 \\
Zealerenol $(\mu \mathrm{g} / \mathrm{kg})$ & 87.4 & 63.4 \\
Deoxynivalenol $(\mu \mathrm{g} / \mathrm{kg})$ & 240.9 & - \\
Fatty acid methyl esters $(\mathrm{mg} / \mathrm{g})$ & & \\
Palmitic $(\mathrm{C} 16: 0)$ & 2.45 & 3.16 \\
Stearic $(\mathrm{C} 18: 0)$ & 0.26 & 0.31 \\
Oleic $(\mathrm{C} 18: 1)$ & 3.87 & 5.73 \\
Linoleic $(\mathrm{C} 18: 2)$ & 9.23 & 11.39 \\
Linolenic $(\mathrm{C} 18: 3)$ & 0.01 & 0.32 \\
\hline
\end{tabular}

"-" represents below limit of detection.

MDA, malondialdehyde; CAT, catalase; POD, peroxidase.

\section{Experimental birds, diets, and management}

The present study was performed on a poultry farm (Yaan, China), and the Animal Care and Use Committee of Sichuan Agricultural University approved all experimental procedures. A total of 216 Lohmann laying hens (50 wk of age) were randomly divided into 6 treatment groups that consisted of 6 replicates for each treatment in a completely randomized design with a $2 \times 3$ factorial arrangement of treatments (Corn $\times$ VE), 2 cages per replicates, 3 birds per cage $(38.1 \mathrm{~cm}$-width $\times$ 50 length $\times 40$ height). Hens were given diets supplemented with one of two corn types (normal corn or aged corn) and 3 concentrations of VE (dl- $\alpha$-tocopheryl acetate, $0,20,100$ $\mathrm{IU} / \mathrm{kg}$ ). Each treatment was uniformly distributed in the laying house to minimize environmental effects. All hens were housed in stainless steel cages and the room environment was controlled at $22^{\circ} \mathrm{C}$ and had a daily lighting schedule of $16 \mathrm{~h}$ light and $8 \mathrm{~h}$ dark. Hens were allowed ad libitum access to experimental diets and water throughout the $12 \mathrm{wk}$ experiment. The basal diet (Table 2) was based on corn and

Table 2. Dietary composition, and formulated energy and nutrient content of the basal diet (air-dried basis, \%)

\begin{tabular}{lc}
\hline Item (\%) & Amount \\
\hline Corn ${ }^{1)}$ & 57.05 \\
Soybean meal, 43\%CP & 22.40 \\
Wheat bran & 7.81 \\
Soybean oil & 2.00 \\
L-lysine & 0.13 \\
DL-methionine & 0.11 \\
Calcium carbonate & 8.35 \\
Calcium hydrophosphate & 1.12 \\
NaCl & 0.40 \\
Choline Chloride & 0.10 \\
Vitamin premix ${ }^{2)}$ & 0.03 \\
Mineral premix ${ }^{3)}$ & 0.50 \\
Calculated nutrient and energy content & \\
ME (MJ/kg) & 11.10 \\
CP & 15.50 \\
Ca & 3.51 \\
Total P & 0.57 \\
Available phosphorus & 0.32 \\
Lysine & 0.79 \\
Methionine & 0.32 \\
Vitamin E ${ }^{4}$ & $8.10(3.13)$ \\
\hline
\end{tabular}

$\mathrm{CP}$, crude protein; ME, metabolizable energy.

1) Corn utilized was supplied entirely from normal or aged in experimental diets.

2) Provided per kilogram of diet: vitamin $A, 8,000 \mathrm{IU}$; vitamin $D_{3}, 1,600 \mathrm{IU}$; vitamin $\mathrm{K}, 0.5 \mathrm{mg}$; vitamin $\mathrm{B}_{1}, 0.8 \mathrm{mg}$; vitamin $\mathrm{B}_{2}, 2.5 \mathrm{mg}$; vitamin $\mathrm{B}_{6}, 3.0$ $\mathrm{mg}$; vitamin $\mathrm{B}_{12}, 0.004 \mathrm{mg}$; folic acid, $0.25 \mathrm{mg}$; niacin, $20 \mathrm{mg}$; Ca-pantothenate acid, $2.2 \mathrm{mg}$; biotin, $0.10 \mathrm{mg}$; vitamin $\mathrm{E}$, according to the amount of each treatment (dl-a-tocopheryl acetate, 0, 20, or $100 \mathrm{mg}$ ).

3) Provided per kg of diet: 60 mg Mn (as $\left.\left.\mathrm{MnSO}_{4}\right) ; 80 \mathrm{mg} \mathrm{Zn} \mathrm{(as} \mathrm{ZnSO}_{4}\right) ; 8$ mg Cu (as $\left.\mathrm{CuSO}_{4} \cdot 5 \mathrm{H}_{2} \mathrm{O}\right) ; 60 \mathrm{mg} \mathrm{Fe}\left(\right.$ as $\mathrm{FeSO}_{4} \cdot 7 \mathrm{H}_{2} \mathrm{O}$ ); $0.35 \mathrm{mg} \mathrm{I}$ (as KI); and $0.30 \mathrm{mg} \mathrm{Se}\left(\mathrm{as} \mathrm{Na}_{2} \mathrm{SeO}_{3} \cdot 5 \mathrm{H}_{2} \mathrm{O}\right)$.

4) $\mathrm{VE}$ content in normal corn and aged corn basal diet was 8.10 and 3.13 IU/kg respectively. 
soybean meal, with composition and nutrient formulation in line with the Agricultural Trade Standardization of China (NY/T33-2004). All diets were provided in mash form.

\section{Assay of antioxidant enzymes in serum, liver, and ovaries}

At the end of the 12 wk experimental period, 6 birds from each treatment were randomly selected (one bird per replicate). Blood $(10 \mathrm{~mL})$ was drawn from the wing vein and placed in tubes to allow serum collection. Feed was not withdrawn from the trough before the blood was collected. After the blood was collected, the tubes containing blood were centrifuged for $10 \mathrm{~min}(3,000 \times \mathrm{g})$ at $4^{\circ} \mathrm{C}$, and then serum was collected in new tubes and stored at $-20^{\circ} \mathrm{C}$ until further analyses of enzyme activity. After blood collection, birds were euthanized by cervical dislocation. Liver and ovary samples were obtained, and a section of each sample was frozen in liquid nitrogen, then stored at $-80^{\circ} \mathrm{C}$ until analyzed for enzyme activity and gene expression. Liver and ovarian samples were homogenized (PowerGen 125, Fisher Scientific, Pittsburgh, PA, USA) for subsequent antioxidant status determination. Analyses included enzymatic activity of superoxide dismutase (SOD) and glutathione peroxidase (GSH-Px) for total antioxidant capacity (T-AOC) and content of malondialdehyde (MDA) using the same procedures as described by instructions with assay kits obtained from Nanjing Jiancheng Bioengineering Institute (Nanjing, Jiangsu, China). Triplicate analyses were performed, and the mean was used for each sample.

\section{Determination of liver lipid metabolism parameters}

Another section of each liver sample was stored at $-20^{\circ} \mathrm{C}$ for the determination of crude fat and cholesterol concentrations. The specific assay kits were purchased from the Nanjing Jiancheng Bioengineering Institute (Nanjing, China). Other liver samples, which were stored at $-80^{\circ} \mathrm{C}$, were analyzed for lipid metabolism parameters and gene expression by means of RNA extraction and measurement.

\section{mRNA expression in liver and/or ovaries}

Total RNA was isolated from frozen livers using Trizol reagent (catalogue No.9109, Takara, Otsu, Japan) according to the manufacturer's instructions. The ratio of absorbance at $260 \mathrm{~nm}$ to at $280 \mathrm{~nm}$ as well as the banding pattern on a $1 \%$ agarose gel were used to verify the purity and quality of RNA samples (Beckman DU-800; Beckman Coulter, Inc., Fullerton, CA, USA). The RNA concentration was determined by measuring absorbance at $260 \mathrm{~nm}$. After extraction of total RNA, followed by reverse transcription (RT) inactivation at $85^{\circ} \mathrm{C}$ for $5 \mathrm{~s}$ using PrimeScriptTM RT reagent kit (catalogue No. RR047A, Takara, Japan). A 1- $\mu \mathrm{L}$ portion of the RT products was used directly for real-time polymerase chain reaction (PCR). Real-time PCR was performed on an ABI-7900 instrument (Advanced Biosystems, Foster, CA, USA). Oligonucleotide primers were used to detect the gene expression of $\beta$-actin, fatty acid synthase (FAS), acetyl-CoA carboxylase $(A C C)$, lipoprotein lipase $(L P L)$, chemokine-like receptor 1 (CMKLR1), GSH-Px, and SOD1 using the SYBR Green system (catalog No. RR820A, Takara, Japan). The sequences of the primers and length of the products are given in Table 3. The reaction mixture $(10 \mu \mathrm{L})$ contained $5 \mu \mathrm{L}$ of fresh SYBR Premix Ex TaqII (Tli RNaseH Plus, Takara, Japan) and $0.2 \mu \mathrm{L}$ ROX Reference Dye II $(50 \times), 0.8 \mu \mathrm{L}$ of the primers,

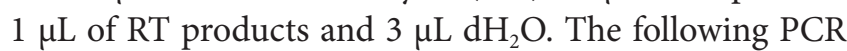
protocol was used with the $\mathrm{ABI}-7900$ : $1 \mathrm{cycle}$ (at $95^{\circ} \mathrm{C}$ for $30 \mathrm{~s}$ ), 40 cycles (at $95^{\circ} \mathrm{C}$ for $5 \mathrm{~s}$ and $60^{\circ} \mathrm{C}$ for $31 \mathrm{~s}$ ) and 1 cycle (at $95^{\circ} \mathrm{C}$ for $15 \mathrm{~s}$, at $60^{\circ} \mathrm{C}$ for $1 \mathrm{~min}$ and at $95^{\circ} \mathrm{C}$ for $15 \mathrm{~s}$ ). The standard curve of each gene was run triplicate for obtaining reliable amplification efficiency values. At the end of amplification, melting curve analysis was performed to identify amplification specificity. $\beta$-Actin transcript was used to standardize the results by eliminating variations in mRNA and cDNA quantity and quality, and each mRNA level was expressed as its ratio to $\beta$-actin mRNA. The relative quantification of gene expression among the treatment groups was analyzed by the $2^{-\Delta \Delta \mathrm{CT}}$ method [13].

\section{Statistical analyses}

The Glimmix procedure of SAS 9.2 (SAS Institute Inc, Cary, NC, USA) was used to test the effects of supplemental VE in normal corn and aged corn diets. Data were analyzed as a $2 \times 3$ (Corn $\times \mathrm{VE})$ factorial arrangement of treatments by 2 -way analysis of variance with a model that included the main effects of corn and VE, as well as their interaction. When an

Table 3. Primers sequence used for the determination of lipid metabolism and antioxidant function of laying hens

\begin{tabular}{llc}
\hline Item & Primer sequence & $\begin{array}{c}\text { Primer } \\
\text { length }\end{array}$ \\
\hline B-actin & $\begin{array}{l}\text { F primer: TGCGTGACATCAAGGAGAAG } \\
\text { R primer: TGCCAGGGTACATTGTGGTA }\end{array}$ & 152 \\
ACC & F primer: CCTGGTCAACGTGATGAATG & 152 \\
& R primer: AGTTCCAGCAGAGGCAAAGA & \\
LPL & F primer: TGCTGGTCCCACCTTTGAGTA & 185 \\
& R primer: TGCAGGACATCCACAAAGTCA & \\
FAS & F primer: ACTGTGGGCTCCAAATCTTCA & 164 \\
& R primer: CAAGGAGCCATCGTGTAAAGC & \\
CMKLR1 & F primer: CGGTCAACGCCATTTGGT & 65 \\
& R primer: GGGTAGGAAGATGTTGAAGAGGAA & \\
GSH-PX & F primer: ATCCGCTTCCACGACTTCC & 137 \\
& R primer: ATCTTCACGTTGCGTTTGCT & \\
SOD1 & F primer: TTGTCTGATGGAGATCATGGCTTC & 98 \\
& R primer: TGCTTGCCTTCAGGATTAAAGTGAG & \\
\hline
\end{tabular}

ACC, acetyl-CoA carboxylase; $L P L$, lipoprotein lipase; FAS, fatty acid synthase; CMKLR1, chemokine-like receptor 1; GSH-PX, glutathione peroxidase; SOD1, superoxide dismutase 1. 
effect was significant, means were compared by Duncan's multiple comparison tests to determine specific differences between means. Statistical significance was assigned at $\mathrm{p}<$ 0.05 .

\section{RESULTS}

Hepatic lipid metabolism and gene expression

Neither aged corn nor dietary VE had any significant influence on hepatic lipid metabolism of laying hens $(p>0.05$;
Table 4), except that the content of low-density lipoprotein cholesterol (LDL-C) in hens fed the aged corn diet was significantly decreased $(\mathrm{p}<0.05)$ compared to normal corn. The relative expression of CMKLR1 in hens fed the aged corn diet was also significantly decreased $(\mathrm{p}<0.05$; Table 5$)$ compared to normal corn. Gene expression of ACC, $L P L$, and FAS showed no significant difference among groups ( $\mathrm{p}>0.05)$.

\section{Antioxidant status in serum}

In hens fed the aged corn diets, the serum content of MDA

Table 4. Effects of vitamin E supplementation on liver lipid metabolism of laying hens fed diets containing aged (4 yr) or normal corn

\begin{tabular}{|c|c|c|c|c|c|c|}
\hline Corn & Vitamin E (IU/kg) & CF (\%) & $\mathrm{TC}(\mathrm{mmol} / \mathrm{g})$ & $\mathrm{HDL}-\mathrm{C}(\mathrm{mmol} / \mathrm{g})$ & LDL-C (mmol/g) & VLDL-C $(\mu \mathrm{mol} / \mathrm{g})$ \\
\hline \multirow[t]{3}{*}{ Normal corn } & 0 & 21.54 & 0.84 & 0.70 & 0.08 & 1.50 \\
\hline & 20 & 21.15 & 0.81 & 0.41 & 0.05 & 1.53 \\
\hline & 100 & 19.06 & 0.80 & 0.35 & 0.10 & 1.47 \\
\hline \multirow[t]{3}{*}{ Aged corn } & 0 & 19.32 & 0.77 & 0.29 & 0.03 & 1.72 \\
\hline & 20 & 18.91 & 0.81 & 0.43 & 0.03 & 1.46 \\
\hline & 100 & 18.38 & 0.87 & 0.34 & 0.02 & 1.64 \\
\hline SEM & & 1.68 & 0.05 & 0.11 & 0.02 & 0.17 \\
\hline \multicolumn{7}{|l|}{ Main effect } \\
\hline \multirow[t]{2}{*}{ Corn } & Normal corn & 20.58 & 0.82 & 0.49 & $0.07^{\mathrm{a}}$ & 1.50 \\
\hline & Aged corn & 18.87 & 0.82 & 0.35 & $0.03^{b}$ & 1.61 \\
\hline Vitamin E & 0 & 20.43 & 0.81 & 0.50 & 0.05 & 1.61 \\
\hline \multirow[t]{2}{*}{$(\mathrm{IU} / \mathrm{kg})$} & 20 & 20.03 & 0.81 & 0.42 & 0.04 & 1.50 \\
\hline & 100 & 18.72 & 0.83 & 0.34 & 0.06 & 1.56 \\
\hline \multirow[t]{3}{*}{ p-value } & Corn & 0.22 & 0.95 & 0.14 & 0.03 & 0.45 \\
\hline & Vitamin E & 0.57 & 0.82 & 0.39 & 0.66 & 0.81 \\
\hline & Corn $\times$ vitamin $\mathrm{E}$ & 0.87 & 0.29 & 0.11 & 0.57 & 0.67 \\
\hline
\end{tabular}

Each mean represents 6 layers.

CF, crude fat; TC, total cholesterol; HDL-C, high-density lipoprotein cholesterol; LDL-C, low-density lipoprotein cholesterol; VLDL-C, very low-density lipoprotein cholesterol; SEM, standard error of the mean.

${ }^{a, b}$ Means with different superscripts within a column differ significantly $(p<0.05)$, and comparisons only conducted within each main effect.

Table 5. Effects of vitamin E supplementation on the relative expression of liver lipid metabolism gene of laying hens fed diets containing aged corn

\begin{tabular}{|c|c|c|c|c|c|}
\hline Corn & Vitamin E (IU/kg) & $A C C$ & $L P L$ & FAS & CMKLR1 \\
\hline \multirow[t]{3}{*}{ Normal corn } & 0 & 1.12 & 1.04 & 1.42 & 1.12 \\
\hline & 20 & 1.40 & 1.54 & 1.72 & 1.43 \\
\hline & 100 & 0.99 & 2.85 & 0.98 & 1.90 \\
\hline \multirow[t]{3}{*}{ Aged corn } & 0 & 1.62 & 1.35 & 1.78 & 0.78 \\
\hline & 20 & 1.66 & 1.33 & 1.24 & 0.81 \\
\hline & 100 & 1.05 & 1.54 & 1.83 & 1.05 \\
\hline SEM & & 0.34 & 0.44 & 0.30 & 0.28 \\
\hline \multicolumn{6}{|l|}{ Main effect } \\
\hline \multirow[t]{2}{*}{ Corn } & Normal corn & 1.17 & 1.81 & 1.37 & $1.48^{\mathrm{a}}$ \\
\hline & Aged corn & 1.45 & 1.41 & 1.62 & $0.88^{b}$ \\
\hline \multirow[t]{3}{*}{ Vitamin E (IU/kg) } & 0 & 1.37 & 1.20 & 1.60 & 0.95 \\
\hline & 20 & 1.53 & 1.44 & 1.48 & 1.12 \\
\hline & 100 & 1.02 & 2.19 & 1.40 & 1.47 \\
\hline \multirow[t]{3}{*}{ p-value } & Corn & 0.33 & 0.26 & 0.32 & 0.01 \\
\hline & Vitamin $E$ & 0.31 & 0.07 & 0.80 & 0.17 \\
\hline & Corn $\times$ vitamin $\mathrm{E}$ & 0.81 & 0.18 & 0.09 & 0.65 \\
\hline
\end{tabular}

Each mean represents 6 laying hens

ACC, acetyl-CoA carboxylase; LPL, lipoprotein lipase; FAS, fatty acid synthase; CMKLR1, chemokine-like receptor 1; SEM, standard error of the mean.

${ }_{a, b}$ Means with different superscripts within a column differ significantly $(p<0.05)$, and comparisons only conducted within each main effect. 
was increased $(\mathrm{p}<0.05)$ and the activity of GSH-Px was decreased $(\mathrm{p}<0.01)$. The activity of SOD was increased with dietary VE addition; with the $100 \mathrm{IU} / \mathrm{kg}$ VE group being significantly higher than the $0 \mathrm{IU} / \mathrm{kg}$ VE group $(\mathrm{p}<0.05)$. The activity of GSH-Px was increased $(\mathrm{p}<0.01)$ in the $20 \mathrm{IU} / \mathrm{kg}$ and $100 \mathrm{IU} / \mathrm{kg}$ VE group compared to $0 \mathrm{IU} / \mathrm{kg} \mathrm{VE}$ group (Table 6).

\section{Antioxidant status in liver}

Compared to the normal corn group, the content of hepatic MDA was increased $(\mathrm{p}<0.05)$ by feeding the aged corn diet, and the activity of SOD was decreased $(\mathrm{p}<0.05)$ by feeding the aged corn diet. Dietary VE had no effect on the hepatic activity of SOD or T-AOC, or on the content of MDA. However, the activity of GSH-Px significantly increased $(\mathrm{p}<0.05)$ with the VE addition in diets (Table 7).

\section{Antioxidant status in ovary}

The activity of SOD was decreased $(\mathrm{p}<0.05)$ in the aged corn diets compared to the normal corn diets (Table 8). The content of MDA was decreased and the activity of SOD, GSH$\mathrm{Px}$, and T-AOC did not show significant differences among

Table 6. Effects of vitamin E supplementation on serum antioxidant status of laying hens fed diets containing aged (4 yr) or normal corn

\begin{tabular}{|c|c|c|c|c|c|}
\hline Corn & Vitamin E (IU/kg) & MDA (nmol/mg) & SOD (U/mg) & GSH-Px (U/mg) & T-AOC (U/mg) \\
\hline \multirow[t]{3}{*}{ Normal corn } & 0 & 5.73 & 4.67 & $1,109.05$ & 3.45 \\
\hline & 20 & 3.89 & 5.17 & $1,404.28$ & 4.42 \\
\hline & 100 & 4.32 & 7.17 & $1,671.91$ & 4.09 \\
\hline \multirow[t]{3}{*}{ Aged corn } & 0 & 6.05 & 5.17 & 980.48 & 3.98 \\
\hline & 20 & 5.73 & 5.25 & $1,102.86$ & 3.29 \\
\hline & 100 & 5.16 & 6.08 & $1,137.62$ & 4.07 \\
\hline SEM & & 0.58 & 0.71 & 83.49 & 0.54 \\
\hline \multicolumn{6}{|l|}{ Main effect } \\
\hline \multirow[t]{2}{*}{ Corn } & Normal corn & $4.64^{b}$ & 5.66 & $1,395.08^{a}$ & 3.99 \\
\hline & Aged corn & $5.65^{\mathrm{a}}$ & 5.50 & $1,073.65^{b}$ & 3.78 \\
\hline \multirow{3}{*}{ Vitamin E (IU/kg) } & 0 & 5.89 & $4.92^{b}$ & $1,044.76^{b}$ & 3.72 \\
\hline & 20 & 4.81 & $5.21^{\mathrm{ab}}$ & $1,253.57^{\mathrm{a}}$ & 3.85 \\
\hline & 100 & 4.74 & $6.63^{\mathrm{a}}$ & $1,404.76^{\mathrm{a}}$ & 4.08 \\
\hline \multirow[t]{3}{*}{ p-value } & Corn & 0.04 & 0.77 & $<0.01$ & 0.64 \\
\hline & Vitamin E & 0.10 & 0.04 & $<0.01$ & 0.79 \\
\hline & Corn $\times$ vitamin $\mathrm{E}$ & 0.42 & 0.52 & 0.07 & 0.31 \\
\hline
\end{tabular}

Each mean represents 6 laying hens

MDA, malondialdehyde; SOD, superoxide dismutase; GSH-Px, glutathinone peroxidase; T-AOC, total antioxidant capacity; SEM, standard error of the mean

$a, b$ Means with different superscripts within a column differ significantly $(p<0.05)$, and comparisons only conducted within each main effect.

Table 7. Effects of vitamin E supplementation on liver antioxidant status of laying hens fed diets containing aged (4 yr) or normal corn

\begin{tabular}{|c|c|c|c|c|c|}
\hline Corn & Vitamin E (IU/kg) & MDA (nmol/mg) & SOD (U/mg) & GSH-Px (U/mg) & $\mathrm{T}-\mathrm{AOC}(\mathrm{U} / \mathrm{mg})$ \\
\hline \multirow[t]{3}{*}{ Normal corn } & 0 & 1.93 & 8.78 & 171.41 & 1.13 \\
\hline & 20 & 0.86 & 9.43 & 241.73 & 1.36 \\
\hline & 100 & 1.03 & 9.74 & 232.13 & 1.08 \\
\hline \multirow[t]{3}{*}{ Aged corn } & 0 & 1.96 & 7.34 & 110.89 & 0.70 \\
\hline & 20 & 1.86 & 8.07 & 240.44 & 0.95 \\
\hline & 100 & 1.76 & 8.61 & 276.19 & 1.16 \\
\hline SEM & & 0.32 & 0.59 & 39.00 & 0.20 \\
\hline \multicolumn{6}{|l|}{ Main effect } \\
\hline \multirow[t]{2}{*}{ Corn } & Normal corn & $1.27^{\mathrm{b}}$ & $9.32^{\mathrm{a}}$ & 215.09 & 1.19 \\
\hline & Aged corn & $1.86^{\mathrm{a}}$ & $8.01^{b}$ & 209.17 & 0.94 \\
\hline \multirow[t]{3}{*}{ Vitamin E (IU/kg) } & 0 & 1.94 & 8.06 & $141.15^{b}$ & 0.91 \\
\hline & 20 & 1.36 & 8.75 & $241.09^{a}$ & 1.16 \\
\hline & 100 & 1.39 & 9.17 & $254.16^{a}$ & 1.12 \\
\hline \multirow[t]{3}{*}{ p-value } & Corn & 0.03 & 0.01 & 0.85 & 0.13 \\
\hline & Vitamin $E$ & 0.13 & 0.18 & 0.01 & 0.43 \\
\hline & Corn $\times$ vitamin $\mathrm{E}$ & 0.30 & 0.97 & 0.42 & 0.36 \\
\hline
\end{tabular}

Each mean represents 6 laying hens

MDA, malondialdehyde; SOD, superoxide dismutase; GSH-Px, glutathinone peroxidase; T-AOC, total antioxidant capacity; SEM, standard error of the mean.

${ }_{a, b}$ Means with different superscripts within a column differ significantly $(p<0.05)$, and comparisons only conducted within each main effect. 
the groups $(\mathrm{p}>0.05)$.

\section{Antioxidant enzyme gene expressions}

As presented in Table 9, expression of SOD1 mRNA in the ovaries was significantly upregulated by feeding of aged corn $(\mathrm{p}<0.01)$. GSH-Px and SOD1 mRNA expression in liver and GSH-Px mRNA expression in the ovaries showed no significant difference among groups fed with normal corn diet and the aged corn diet ( $p>0.05$ ). Compared to 0 and $20 \mathrm{IU} / \mathrm{kg} \mathrm{VE}$ diet groups, expression of SOD1 mRNA in the liver and ova- ries were significantly increased when birds were fed diets containing $100 \mathrm{IU} / \mathrm{kg} \mathrm{VE}$. The observed interaction between corn and VE $(\mathrm{p}<0.05)$ was that GSH-Px and SOD1 mRNA expression in the ovaries was higher in aged corn diet containing $100 \mathrm{IU}$ of $\mathrm{VE} / \mathrm{kg}$ versus those fed aged corn at lower VE supplementation.

\section{DISCUSSION}

Previous studies have shown changes in the chemical com-

Table 8. Effects of vitamin E supplementation on ovary antioxidant status of laying hens fed diets containing aged (4 yr) or normal corn

\begin{tabular}{|c|c|c|c|c|c|}
\hline Corn & Vitamin E (IU/kg) & MDA (nmol/mg) & SOD (U/mg) & GSH-Px (U/mg) & T-AOC (U/mg) \\
\hline \multirow[t]{3}{*}{ Normal corn } & 0 & 0.17 & 8.34 & $1,029.39$ & 0.51 \\
\hline & 20 & 0.12 & 9.49 & $1,365.82$ & 0.62 \\
\hline & 100 & 0.07 & 9.48 & $1,063.40$ & 0.67 \\
\hline \multirow[t]{3}{*}{ Aged corn } & 0 & 0.16 & 7.48 & 739.78 & 0.47 \\
\hline & 20 & 0.15 & 7.11 & $1,199.04$ & 0.49 \\
\hline & 100 & 0.15 & 8.95 & $1,146.48$ & 0.51 \\
\hline SEM & & 0.03 & 0.63 & 396.42 & 0.12 \\
\hline \multicolumn{6}{|l|}{ Main effect } \\
\hline \multirow[t]{2}{*}{ Corn } & Normal corn & 0.12 & $9.10^{a}$ & $1,152.87$ & 0.60 \\
\hline & Aged corn & 0.15 & $7.84^{b}$ & $1,028.43$ & 0.49 \\
\hline \multirow[t]{3}{*}{ Vitamin E (IU/kg) } & 0 & 0.16 & 7.91 & 884.58 & 0.49 \\
\hline & 20 & 0.13 & 8.30 & $1,282.43$ & 0.56 \\
\hline & 100 & 0.11 & 9.21 & $1,104.94$ & 0.59 \\
\hline \multirow[t]{3}{*}{$p$-value } & Corn & 0.13 & 0.02 & 0.70 & 0.27 \\
\hline & Vitamin E & 0.22 & 0.12 & 0.61 & 0.72 \\
\hline & Corn $\times$ vitamin $E$ & 0.24 & 0.31 & 0.89 & 0.86 \\
\hline
\end{tabular}

Each mean represents 6 laying hens.

MDA, malondialdehyde; SOD, superoxide dismutase; GSH-Px, glutathinone peroxidase; T-AOC, total antioxidant capacity; SEM, standard error of the mean

a,b Means with different superscripts within a column differ significantly $(p<0.05)$, and comparisons only conducted within each main effect.

Table 9. Effects of vitamin E supplementation on the relative expression of liver and ovary antioxidant gene of laying hens fed diets containing aged (4 yr) or normal corn

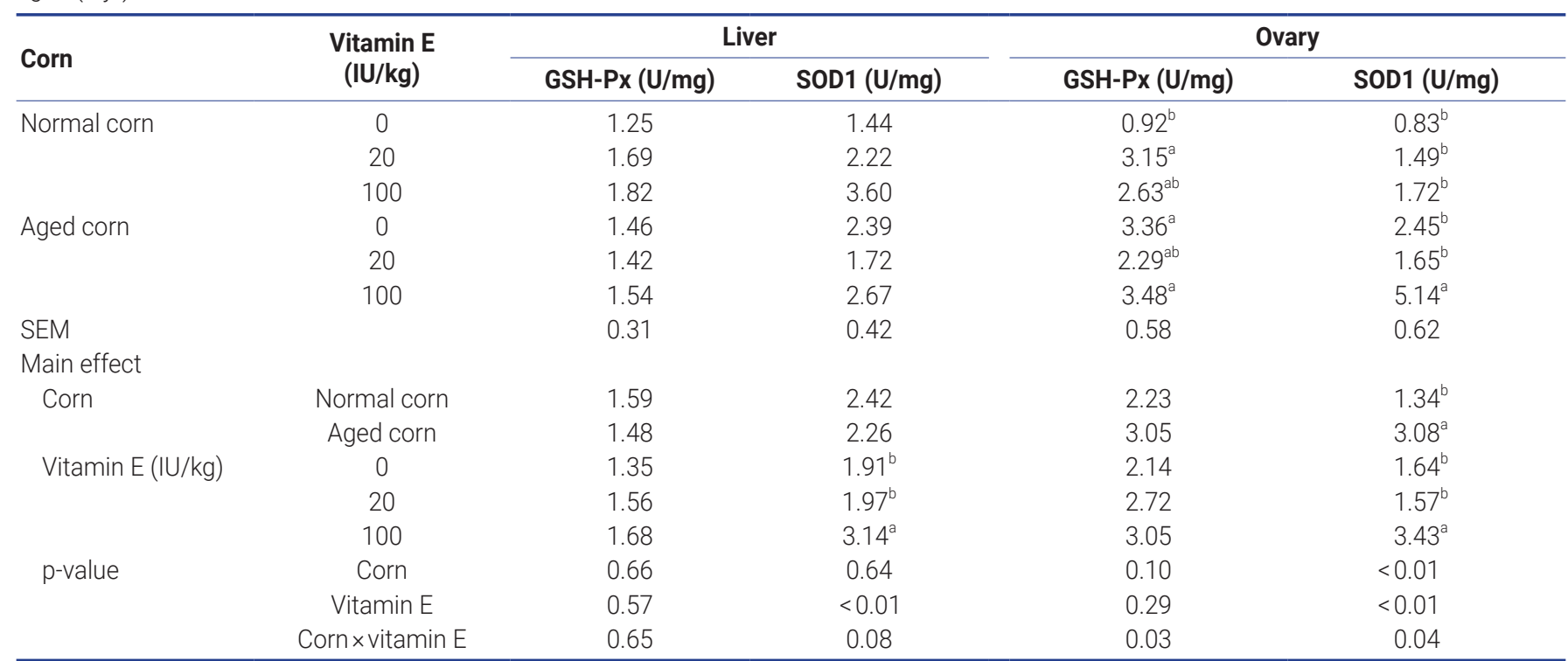

Each mean represents 6 laying hens.

GSH-PX, glutathione peroxidase; SOD1, superoxide dismutase 1; SEM, standard error of the mean.

a,b Means with different superscripts within a column differ significantly $(p<0.05)$, and comparisons only conducted within each main effect. 
position and nutritive value of cereal grains during storage [14]. The fatty acid value and POD activity are important parameters for the quality evaluation of corn in storage. In our study, the content of MDA and the acidity of fatty acids in aged corn were higher than the normal corn, while the CAT and POD in aging corn were lower than the normal corn. The activity of CAT and POD in corn gradually decreased with increased storage time [15]. Meanwhile, the fatty acid (FA) profile in aged corn was different than normal corn. The content of mycotoxins was small, so the effects of aged corn on hens in this experiment were caused by changes in the nutritional components of corn, such as oxidation of fatty acids.

The cholesterol content of the yolk is primarily dependent on the cholesterol content of triglyceride-rich lipoproteinsvery low-density lipoprotein (VLDL) and vitellogenin. Almost 95\% cholesterol is derived from VLDL made in the liver, where it is synthesized and transported in the plasma to the ovaries where they are taken up into the developing follicles by receptor mediated endocytosis [16]. When lipid peroxidation products present in oxidized oils were fed to rats and laying hens, it caused a reduction in the concentration of triacylglycerols and cholesterol in the liver and plasma [17]. In the present study, no differences in liver total cholesterol (TC) were observed. This result was in accordance with a previous study, which showed no differences in the level of hepatic TC in laying hens fed oxidized oil [18]. Serum TC was not significantly affected by oxidized sunflower oil in rats [13]. However, aged corn significantly decreased the content of LDL-C in the liver. Oxidized sunflower oil significantly decreased liver TC, high-density lipoprotein cholesterol (HDLC) and VLDL-cholesterol (VLDL-C) content in rats [15]. In our previous study, aged corn significantly decreased the cholesterol content including TC, LDL-C, and VLDL-C in serum [13]. Dietary VE supplementation in lacaune ewes decreased serum LDL-C content [19] which agrees with [20] who found VE decreased the content of TC, total triglyceride (TG), HDL-C, and VLDL-C in serum of rats. In this study, VE supplementation did not affect the lipid metabolism in laying hens. In our study, the aged corn was less oxidized than the oxidized soybean oil [18] and sunflower oils used in other prior studies [21,22]; therefore, the decrease in crude fat and TC was not significant.

CMKLR1, a G protein-coupled receptor, and its ligand chemerin are known to be involved in adipogenesis [23]. CMKLR1 is expressed in the liver [24]. In human and rodent fatty liver, and in fibrotic liver of mice fed a methioninecholine deficient diet, CMKLR1 is reduced [25]. Lipid loading of hepatocytes does not affect CMKLR1 levels, similar to adipocytes where enhanced triglyceride accumulation has no effect on this receptor [26]. In the present study, CMKLR1 mRNA expression was significantly decreased in the hens fed the aged corn.

The intake of exogenous free radicals can cause a decrease in antioxidants. The storage of corn resulted in many free radicals, and laying hens fed aged corn had a lower serum antioxidant status [6]. The hens fed aged corn were more susceptible to oxidative damage and decreased laying performance [7]. Oxidative stress induced by lipid peroxidation products has been proposed as a possible mechanism involved in the toxicity of thermally oxidized oil [27]. Exposure to oxidized sunflower oil increased plasma MDA, hepatic reactive oxygen species and carbonyl group concentrations [28]. The antioxidant enzymes SOD and GSH-Px are the main elements of the first level of antioxidant defense in the cell because they form a major protective system against oxidative damage. In the present study, serum and liver MDA were significantly increased, the serum GSH-Px, liver and ovary SOD were significantly decreased in hens fed the aged corn. These results suggest that enhanced peroxidation leads to an imbalance of the pro-oxidant/antioxidant system. The VE is a potent chain breaking antioxidant, and its primary role is to prevent lipids peroxidative damage in the tissue [29]. In our study, dietary VE supplementation elevated the activities of SOD in serum and GSH-Px both in serum and liver of laying hens. Our results are consistent with a previous study, which showed VE improved the activities of total SOD (T-SOD) and GSH-Px in plasma and liver of laying hens fed with the oxidized sunflower oil diet [28]. Our results did not show significant effects of aged corn and VE on ovarian antioxidant parameters. However, the relative expression of ovarian SOD1 mRNA was increased in hens fed the aged corn diets. This is inconsistent with the activity of SOD being decreased in ovaries of layers fed with the aged corn diet, which may be relevant to how much of the SOD1 mRNA was translated. This indicates that aged corn (or metabolites) may regulate the expression of antioxidant enzyme genes at the level of transcription and translation. In general, these results showed that feeding aged corn leads to an imbalance of the pro-oxidant/antioxidant system, and VE supplementation efficiently reversed this imbalance.

\section{CONCLUSION}

In conclusion, feeding aged corn affected lipid metabolism and decreased the antioxidant function of laying hens. Dietary supplementation of VE was unable to counteract the negative effects of aged corn on lipid metabolism in laying hens. However, addition of $100 \mathrm{IU} / \mathrm{kg}$ VE prevented aged corn-induced lipid peroxidation in laying hens, possibly via a direct increase in antioxidant enzyme activities and enhancing the relative expressing of antioxidant genes. Future studies will be performed and will hopefully confirm or reproduce the results of the current study. 


\section{CONFLICT OF INTEREST}

We certify that there is no conflict of interest with any financial organization regarding the material discussed in the manuscript.

\section{ACKNOWLEDGMENTS}

This work was supported by National Key R \& D Program (2016YFD0501202) and 111 project. We also want to thank Gregory S. Fraley (Professor Biology, Hope College, Holland, MI, USA) and Todd J. Applegate (Professor, Department of Poultry Science, University of Georgia) for giving us lots of suggestions on this manuscript.

\section{REFERENCES}

1. Choct M, Hughes RJ. The new season grain phenomenon: the role of endogenous glycanases in the nutritive value of cereal grains in broiler chickens. Australia: Rural Industries Research and Development Corporation; 2000.

2. McDonough CM, Floyd CD, Waniska RD, Rooney LW. Effect of accelerated aging on maize, sorghum, and sorghum meal. J Cereal Sci 2004;39:351-61. https://doi.org/10.1016/j.jcs.2004. 01.001

3. Rehman ZU. Storage effects on nutritional quality of commonly consumed cereals. Food Chem 2006;95:53-7. https:// doi.org/10.1016/j.foodchem.2004.12.017

4. Galliard T. Hydrolytic and oxidative degradation of lipids during storage of wholemeal flour: effects of bran and germ components. J Cereal Sci 1986;4:179-92. https://doi.org/10. 1016/S0733-5210(86)80020-0

5. Bailly C, Bogatek-Leszczynska R, Come D, Corbineau F. Changes in activities of antioxidant enzymes and lipoxygenase during growth of sunflower seedlings from seeds of different vigour. Seed Sci Res 2002;12:47-55. https://doi.org/10.1079/ SSR200197

6. Liu B, He YY, Yin DF, Xia ZF, Yuan JM. Corn at different storage periods affects serum antioxidant function of broilers. Chin J Anim Nutr 2013;25:1077-84.

7. McFarlane JM, Curtis SE, Shanks RD, Carmer SG. Multiple concurrent stressors in chicks.: 1. Effect on weight gain, feed intake, and behavior. Poult Sci 1989;68:501-9. https://doi.org/ 10.3382/ps.0680501

8. Attia YA, Abd El-Hamid AE, Abdallah AA, et al. Effect of betaine, vitamin $\mathrm{C}$ and vitamin $\mathrm{E}$ on egg quality, hatchability, and markers of liver and renal functions in dual-purpose breeding hens exposed to chronic heat stress. Eur Poult Sci 2018;82:226. https://doi.org/10.1399/eps.2018.226

9. Zhang YR, Wang Z, Cai SM, et al. Effects of aging corn diet supplemented with tea polyphenol, vitamin $\mathrm{E}$ and butylated hydroxytoluene on growth performance and antioxidant function of meat ducks. Chin J Anim Nutr 2015;27:118490.

10. Jiang W, Zhang L, Shan A. The effect of vitamin $\mathrm{E}$ on laying performance and egg quality in laying hens fed corn dried distillers grains with solubles. Poult Sci 2013;92:2956-64. https://doi.org/10.3382/ps.2013-03228

11. Lu T, Harper AF, Dibner JJ, et al. Supplementing antioxidants to pigs fed diets high in oxidants: II. Effects on carcass characteristics, meat quality, and fatty acid profile. J Anim Sci 2014; 92:5464-75. https://doi.org/10.2527/jas.2013-7112

12. Mu Y, Zhang K, Bai S, Wang JP, Zeng Q, Ding X. Effects of vitamin $\mathrm{E}$ supplementation on performance, serum biochemical parameters and fatty acid composition of egg yolk in laying hens fed a diet containing ageing corn. J Anim Physiol Anim Nutr 2019;103:135-45. https://doi.org/10.1111/jpn.13017

13. Livak KJ, Schmittgen TD. Analysis of relative gene expression data using real-time quantitative PCR and the $2^{-\Delta \Delta C \mathrm{~T}}$ method. Methods 2001;25:402-8. https://doi.org/10.1006/meth.2001. 1262

14. Chrastil J. Protein-starch interactions in rice grains. Influence of storage on oryzenin and starch. J Agric Food Chem 1990; 38:1804-9. https://doi.org/10.1021/jf00099a005

15. Zhang Y, Zhou X, Zhang Y. Research on membrane lipid peroxidation and physiological parameters of storage maize. Sci Agric Sin 2008;41:3410-4.

16. Elkin RG. Reducing shell egg cholesterol content. I. Overview, genetic approaches, and nutritional strategies. Worlds Poult Sci J 2006;62:665-87. https://doi.org/10.1017/S00439339060 01206

17. Chao PM, Chao CY, Lin FJ, Huang C. Oxidized frying oil up-regulates hepatic acyl-CoA oxidase and cytochrome $\mathrm{P}_{450}$ 4 A1 genes in rats and activates PPAR $\alpha$. J Nutr 2001;131:316674. https://doi.org/10.1093/jn/131.12.3166

18.Yue HY, Wang J, Qi XL, et al. Effects of dietary oxidized oil on laying performance, lipid metabolism, and apolipoprotein gene expression in laying hens. Poult Sci 2011;90:1728-36. https://doi.org/10.3382/ps.2011-01354

19. Casamassima D, Nardoia M, Palazzo M, Vizzarri F, Corino C. Effect of dietary extruded linseed, verbascoside and vitamin E supplements on selected serum biochemical parameters and plasma oxidative status in lacaune ewes. Slov Vet Res 2014;51:89-100.

20. Dou M, Ma AG, Wang QZ, et al. Supplementation with magnesium and vitamin $\mathrm{E}$ were more effective than magnesium alone to decrease plasma lipids and blood viscosity in diabetic rats. Nutr Res 2009;29:519-24. https://doi.org/10.1016/j.nutres. 2009.07.001

21. Ammouche A, Rouaki F, Bitam A, Bellal MM. Effect of ingestion of thermally oxidized sunflower oil on the fatty acid composition and antioxidant enzymes of rat liver and brain in development. Ann Nutr Metab 2002;46:268-75. https:// doi.org/10.1159/000066496 
22. Koch A, König B, Spielmann J, Leitner A, Stangl GI, Eder K. Thermally oxidized oil increases the expression of insulininduced genes and inhibits activation of sterol regulatory element-binding protein-2 in rat liver. J Nutr 2007;137:201823. https://doi.org/10.1093/jn/137.9.2018

23. Yoshimura T, Oppenheim JJ. Chemokine-like receptor 1 (CMKLR1) and chemokine (C-C motif) receptor-like 2 (CCRL2); two multifunctional receptors with unusual properties. Exp Cell Res 2011;317:674-84. https://doi.org/10. 1016/j.yexcr.2010.10.023

24. Parlee SD, Ernst MC, Muruganandan S, Sinal CJ, Goralski KB. Serum chemerin levels vary with time of day and are modified by obesity and tumor necrosis factor- $\alpha$. Endocrinology 2010;151:2590-602. https://doi.org/10.1210/en.2009-0794

25. Wanninger J, Bauer S, Eisinger K, et al. Adiponectin upregulates hepatocyte CMKLR1 which is reduced in human fatty liver. Mol Cell Endocrinol 2012;349:248-54. https://doi.org/ 10.1016/j.mce.2011.10.032

26. Bauer S, Wanninger J, Schmidhofer S, et al. Sterol regulatory element-binding protein 2 (SREBP2) activation after excess triglyceride storage induces chemerin in hypertrophic adipocytes. Endocrinology 2011;152:26-35. https://doi.org/10.1210/ en.2010-1157

27. Ng CY, Leong XF, Masbah N, et al. Reprint of "heated vegetable oils and cardiovascular disease risk factors". Vasc Pharmacol 2014;62:38-46. https://doi.org/10.1016/j.vph.2014.05.003

28. Wang J, Zhang HJ, Xu L, et al. Dietary supplementation of pyrroloquinoline quinone disodium protects against oxidative stress and liver damage in laying hens fed an oxidized sunflower oil-added diet. Animal 2016;10:1129-36. https:/doi. org/10.1017/S175173111600001X

29. Burton GW, Traber MG. Vitamin E: antioxidant activity, biokinetics, and bioavailability. Annu Rev Nutr 1990;10:35782. https://doi.org/10.1146/annurev.nu.10.070190.002041 